SCientia Marina $70(2)$

June 2006, 319-323, Barcelona (Spain)

ISSN: 0214-8358

\title{
Three new exotic fish records from the SE Aegean Greek waters
}

\author{
MARIA CORSINI ${ }^{1}$, PANAGIOTIS MARGIES ${ }^{2}$, GERASIMOS KONDILATOS ${ }^{1}$ \\ and PANOS S. ECONOMIDIS ${ }^{3}$ \\ ${ }^{1}$ Hellenic Center for Marine Research/Hydrobiological Station of Rhodes. Cos Street, 85100 Rhodes, Greece. \\ E-mail: mcorsini-foka@hsr-ncmr.gr \\ ${ }^{2}$ Aristotle University of Thessaloniki, School of Veterinary Medicine, Thessaloniki, Greece. \\ ${ }^{3}$ Karakasi 79, GR-54453 Thessaloniki, Greece.
}

\begin{abstract}
SUMMARY: Three exotic fish, Iniistius pavo (Labridae) and Lagocephalus sceleratus (Tetraodontidae), Lessepsian immigrants, and Seriola fasciata (Carangidae) of Atlantic origin, were recorded in the marine area of Rhodes Island (SE Aegean Sea, Greece). The first species is a new record for the Mediterranean Sea, the second is new for Greek waters, while the occurrence of the third is registered for the first time in the eastern Mediterranean Sea.
\end{abstract}

Keywords: Lessepsian migration, exotic fish, Iniistius pavo, Lagocephalus sceleratus, Seriola fasciata, Mediterranean Sea.

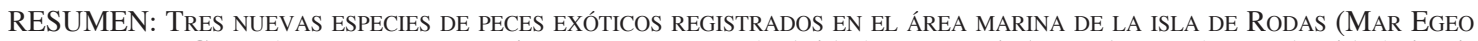
SUD ORIENTAL, GRECIA). - Tres peces exóticos, Iniistius pavo (Labridae), Lagocephalus sceleratus (Tetraodontidae), inmigrantes lessepsianos, y Seriola fasciata (Carangidae), especie del Atlántico, se registraron en el área marina de la isla de Rodas (mar Egeo sudoriental, Grecia). La primera especie es nueva para el Mediterráneo, la segunda es nueva para aguas griegas, y la tercera es registrada por la primera vez en el Mediterráneo oriental.

Palabras clave: migración lessepsiana, peces exóticos, Iniistius pavo, Lagocephalus sceleratus, Seriola fasciata, mar de Mediterráneo.

The majority of exotic marine species listed in Hellenic waters have been recorded in the southeast Aegean Sea, particularly in the continental shelves of Rhodes and the Dodecanese Islands. About $90 \%$ of this biota consists of Lessepsian migrant species and the frequency of their records is increasing in the area (Pancucci-Papadopoulou et al., 2005; Corsini et al., 2005).

In this paper two more Indo-Pacific fish species, Iniistius pavo Valenciennes, 1840, new in the Mediterranean and Lagocephalus sceleratus (Gmelin, 1789), new for Greek waters, are presented. Additionally, the first occurrence in the eastern Mediterranean of the carangid of Atlantic origin Seriola fasciata (Bloch, 1793) is reported.
The juvenile I. pavo specimen was identified according to Randall (1986), Randall and Earle (2002) and Victor et al. (2001). Randall (pers. comm., 2005) revised an initial misidentification of the specimen as Xyrichtys niger (Steindachner, 1900) (Randall, 1981), claiming that the black specimen "is a colour phase of X. pavo" (Fig. 1). It was captured on August 2004 in the Plimmiris area, SE coast of Rhodes, at a depth of $2.5 \mathrm{~m}$, on a sandy bottom with rocks around, sea temperature $28^{\circ} \mathrm{C}$.

The specimen of $L$. sceleratus was identified according to Smith and Heemstra (1986a) and Akyol et al. (2005). It was caught by a fishing-rod on 21 September 2005 at Ladiko, SE coast of Rhodes, at a depth of 15-20 m, on a sandy bottom. 
The rather juvenile $S$. fasciata specimen was identified according to Smith-Vaniz (1986) and Golani et al. (2002). It was caught in November 2004 by a trawl-net at a depth of 50 to $80 \mathrm{~m}$ off Ialissos-Trianda Bay, NW coast of Rhodes, with a sea temperature at the surface of $21^{\circ} \mathrm{C}$, and sandy to muddy bottom.

The samples are deposited at the Hydrobiological Station of Rhodes Collection.

\section{DESCRIPTION OF SPECIMENS}

The morphometric measurements and meristic counts of fish specimens were performed according to Smith and Heemstra (1986b) and Bauchot (1987).

Abbreviations. Total length: TL, Fork length: FL, Standard length: SL, Maximum body depth: H, Minimum body depth: h, Caudal peduncle length: lpc, Head length: HL, Eye diameter: Oh, Preorbital distance: prO, Postorbital distance: poO, Interorbital distance: $\mathrm{iO}$, Base of dorsal fin: $\mathrm{bD}$, Base of $1^{\text {st }}$ dorsal fin: $\mathrm{bD}_{1}$, Base of $2^{\text {nd }}$ dorsal fin: $\mathrm{bD}_{2}$, Base of anal fin: $b A$, Pectoral fin length: PL, Ventral fin length: VL, Ventral-Anal distance: V-A, Predorsal distance: pD, Preventral distance: pV, Preanal distance: $p A$. Ratios are given as \% in SL or in HL. Meristic counts comprehended spines (designated by Roman numerals) and soft rays (Arabic numerals) of dorsal $\left(\mathrm{D}\right.$ or $\left.\mathrm{D}_{1}, \mathrm{D}_{2}\right)$, anal $(\mathrm{A})$, pectoral $(\mathrm{P})$, ventral $(\mathrm{V})$ and caudal $(\mathrm{C})$ fins.
Iniistius pavo. $\mathrm{D}$ : $\mathrm{II}+\mathrm{VII}+12, \mathrm{~A}: \mathrm{III}+12, \mathrm{P}: 12, \mathrm{~V}$ : I+5, C: 15 (broken). SL $43.8 \mathrm{~mm}$, weight $5.2 \mathrm{~g} . \mathrm{H}$ 34.2 SL, h 13.7 SL, lpc 10.3 SL, HL 30.8 SL, Oh $23.0 \mathrm{HL}$, prO $26.7 \mathrm{HL}$, poO $53.3 \mathrm{HL}$, iO 14.1 HL, bD 62.1 SL, bA 45.2 SL, PL 17.6 SL, VL 14.2 SL, V-A 17.1 SL, pD 18.9 SL, pV 27.4 SL, pA 45.7 SL. The first two dorsal spines are separated from the rest of the dorsal fin and longer $\left(1^{\text {st: }}: 7.2 \mathrm{~mm}, 2^{\text {nd: }}: 6.7\right.$ $\mathrm{mm}, 3^{\text {rd: }} 3.3 \mathrm{~mm}$ ) (Victor et al., 2001, Randall and Earle, 2002). The origin of the first dorsal spine is distinctly behind the eye. The lateral line is interrupted: (20)+(6). The body is deep and compressed. The dorsal profile of the snout is not steep, sloping at an angle of about $55^{\circ}$. The eye is nearer the mouth than the dorsal profile of the head, the front of the head not ending in a fleshly keel. Two large canines are present in both the upper and lower jaws. The body colour in life is dark black, the posterior part of the caudal fin is transparent whitish, the margins of dorsal fin lightly reddish and the eyes reddish (Randall and Earle, 2002). The specimen was damaged due to the transport (Fig. 1).

The $I$. pavo is a wide-ranging Indo-Pacific (including the Red Sea) and eastern Pacific species (Victor et al., 2001; Randall and Earle, 2002; Froese and Pauli, 2005).

Lagocephalus sceleratus. D: 12, A: 11, P: 17, C: 20. TL $376 \mathrm{~mm}$, FL $354 \mathrm{~mm}$, SL $335 \mathrm{~mm}$, weight 648.5 g. H 19.1 SL, h 3.0 SL, lpc 26.6 SL, HL 31.6 SL, Oh 22.6 HL, prO 48.9 HL, poO 27.4 HL, iO 38.0

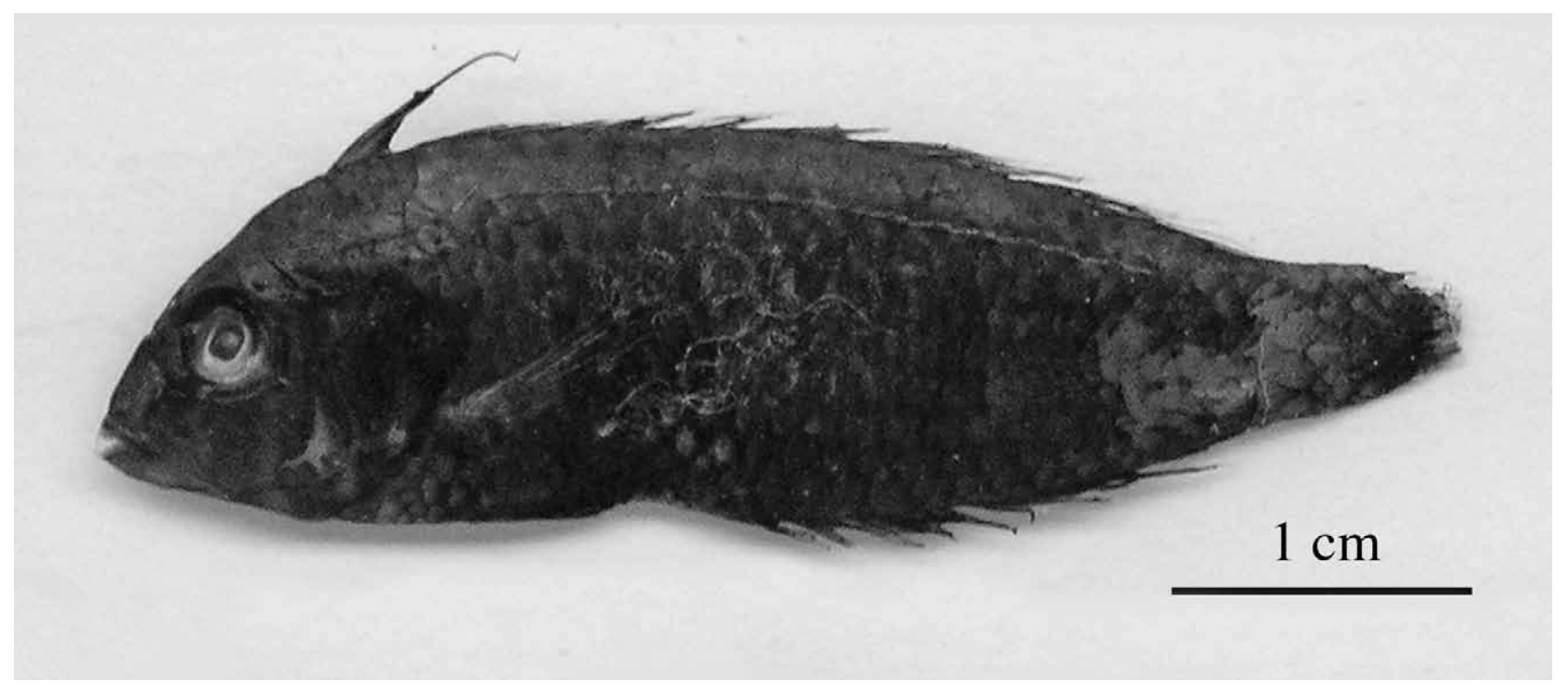

FIG. 1. - Iniistius pavo specimen preserved in formaldehyde. 


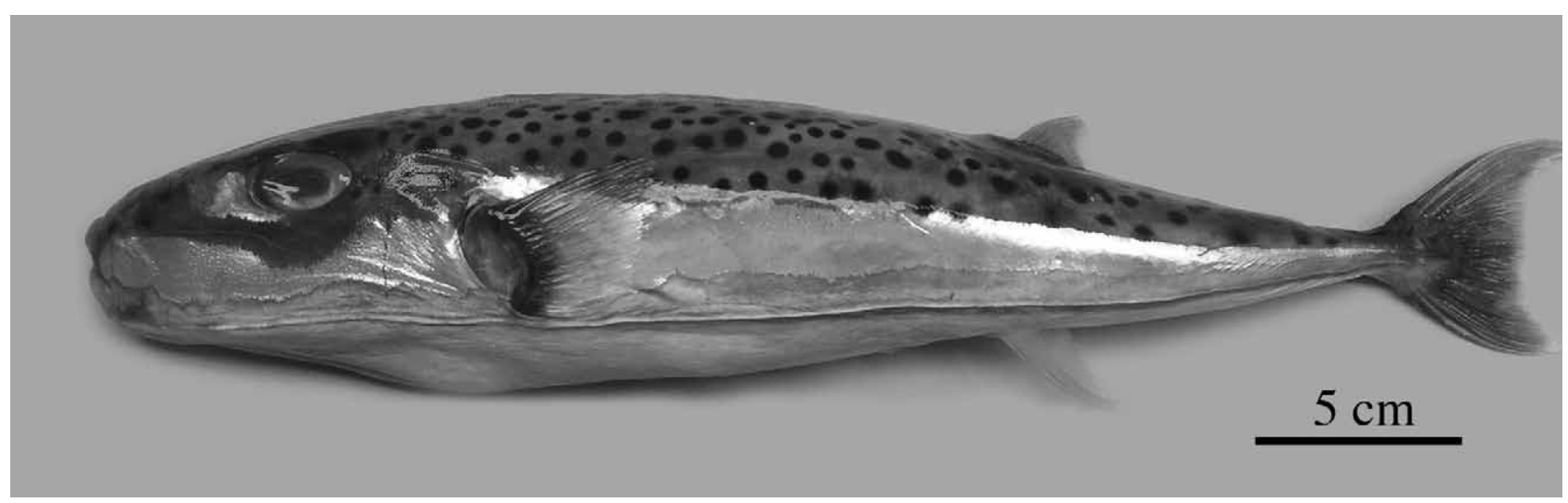

FIG. 2. - Lagocephalus sceleratus specimen, after defrosting.

HL, bD 5.5 SL, bA 5.2 SL, PL 12.2 SL, pD 66.0 SL, pA 65.7 SL. The body is elongated. The dorsal and anal fins are posterior in position and opposite, the caudal fin is lunate. Small spinules are present on the dorsal area, extending from behind the upper lip to the dorsal fin, while ventrally the spinules do not reach the anus. No scales are present on the rest of the body surface. Colour of defrosted specimen: dorsally it is greyish to greenish with circular or ellipsoid black spots. A silver band originates from behind the upper lip and extends to the caudal fin base. In front of and below the eye a silver blotch almost reaches $1 / 3$ of the horizontal eye diameter. The belly is whitish. The pectoral base and inside of gills are black (Fig. 2).
The species inhabits the Indo-West Pacific and the Red Sea (Froese and Pauli, 2005) and it has been recorded recently for the first time in Turkish waters, SE Aegean Sea (Akyol et al., 2005).

Seriola fasciata. $\mathrm{D}_{1}:$ VIII, $\mathrm{D}_{2}: \mathrm{I}+32$, A: II+I+19, P: I+19, V: I+5, C: 22 (soft). TL 198 mm, FL 177 mm, SL 168 mm, weight 133.5 g. H 38.2 SL, h 5.9 SL, lpc 9.4 SL, HL 28.6 SL, Oh 22.5 HL, prO 32.1 HL, poO $47.9 \mathrm{HL}, \mathrm{iO} 40.8 \mathrm{HL}, \mathrm{bD}_{1} 10.7 \mathrm{SL}, \mathrm{bD}_{2} 45.2 \mathrm{SL}, \mathrm{bA}$ 27.1 SL, PL 14.7 SL, VL 21.5 SL, V-A 30.4 SL, pD 27.9 SL, pV 31.5 SL, pA 60.2 SL. The body is elongated, laterally compressed, with terminal mouth. The two dorsal fins are not connected to each other. The

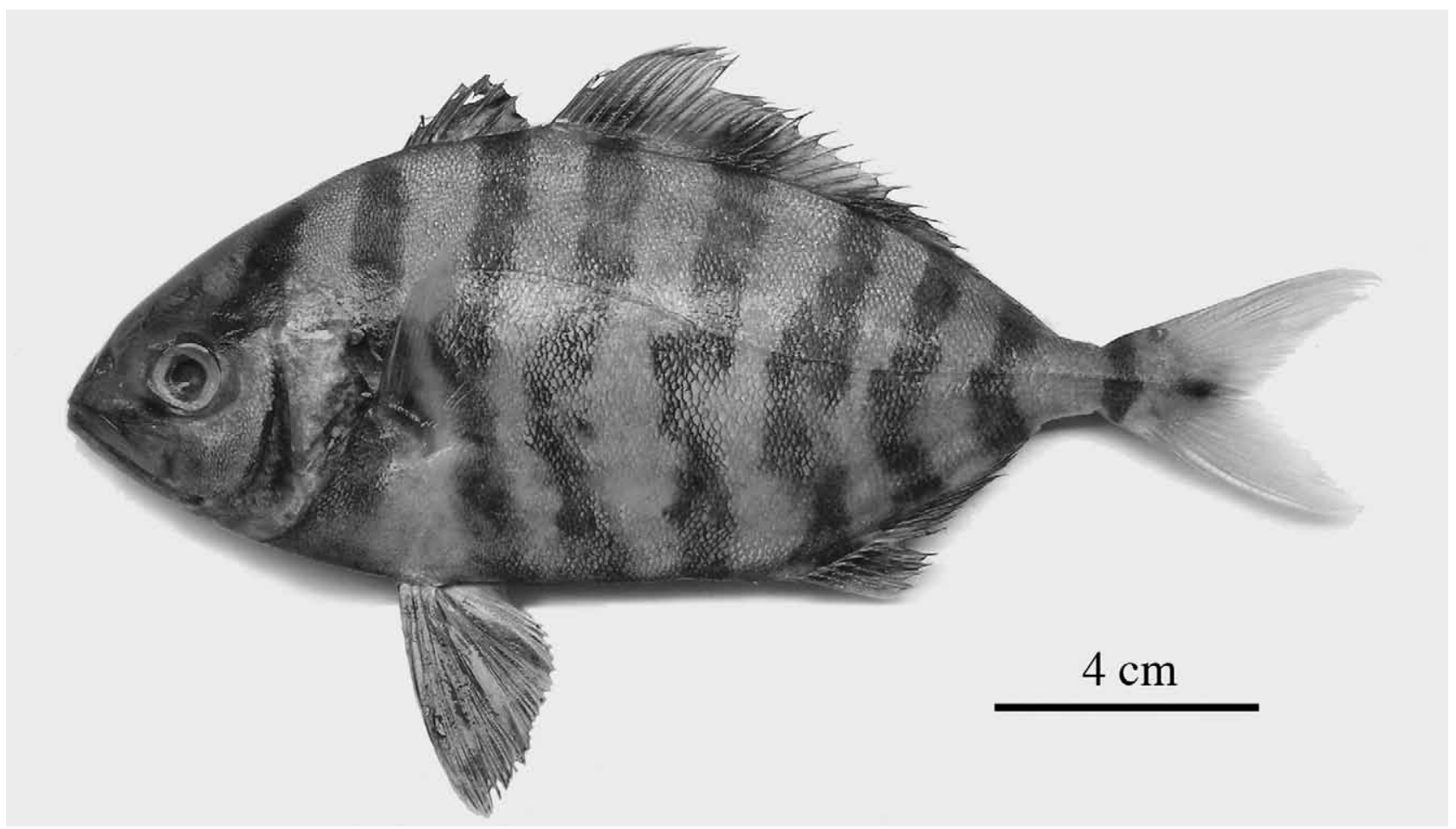

FIG. 3. - Seriola fasciata specimen, after defrosting. 
length of the $2^{\text {nd }}$ dorsal fin lobe is $11 \%$ shorter than PL and $12 \%$ of FL (Smith-Vaniz, 1986). No scutes in lateral line, caudal peduncle grooves present. Colour of defrosted specimen: the body is yellowish, particularly on the dorsal part, above the lateral line, which is curved above the pectoral fin. There are seven dark vertical bars on the sides of the body, which extend from the middle dorsal line to the middle abdominal line. They are irregular and broken, the third to the seventh extending onto the inter-radial membranes of the second dorsal fin, the fifth to the seventh onto the anal fin (Smith-Vaniz, 1986; Golani et al., 2002). In addition, a bar is located on the head extending from the eye to the front, while another one is present on the caudal peduncle and a black spot appears on the caudal fin base (Fig. 3).

The species has a sub-tropical distribution, appearing in the western and eastern Atlantic (Golani et al., 2002; Froese and Pauli, 2005). In the Mediterranean, it was first recorded in the Balearic Islands (Massutí and Stefanescu, 1993), successively in the southern Tyrrhenian Sea, off Sicily and Lampedusa, in the Sicilian channel (Andaloro and Potoschi, 1997), in the Gulf of Lions (Quignard and Tomasini, 2000), and in the Gulf of Gabes (Bradai, 2000).

\section{REMARKS}

The present discovery of I. pavo in Dodecanese waters brings the total number of the Red Sea fish species which have colonized (or are colonizing) the eastern Mediterranean up to 63 (Golani et al., 2002; Golani et al., 2004; Corsini et al., 2005; Akyol et al., 2005, Sinis, 2005). Several of these Erythrean colonizing fishes are "relegated" to the Levant Basin, while some others have already expanded their distribution to the central Mediterranean (Catalano and Zava, 1993, Azzurro et al., 2004, Azzurro and Andaloro, 2004, Ben Soussi et al., 2004), and others have expanded as far as the Adriatic Sea (Dulčić and Pallaoro, 2003).

Currently there are six non-indigenous tetraodontids species in the Mediterranean (Golani et al., 2002; Corsini et al., 2005; Akyol et al., 2005) and the occurrence of L. sceleratus in Rhodes shows that its population is continuing to spread in the SE Aegean Sea.

There are 33 alien Atlantic fish species in the Mediterranean (Golani et al., 2002, 2004; Ben Soussi et al., 2005), some of which, such as Sphoeroides pachygaster (Müller and Troschel, 1848), S. fasciata and S. carpenteri Mather, 1971 have reached significant biomasses (Andaloro, 2001). It should be noted that $S$. pachygaster, from its first recording in Mallorca (Oliver, 1981), gradually expanded its distribution to the entire Mediterranean (Golani et al., 2002; Eryilmaz et al., 2003).

The successive recordings from west to east of $S$. fasciata obviously suggest a successful adaptation of the species to the warm waters of the south Mediterranean and its progressive establishment there (Andaloro et al., 2005).

The scientific community is increasingly interested in the phenomenon of the biological invasion, and the flux of invaders is continuous (Streftaris et al., 2005). The present case, which involves both Erythrean and Atlantic colonizing fishes in the SE Aegean Sea, may also suggest that the gradual warming of the area, occurring over the last period (Kevrikidis and Galil, 2003), also facilitates the immigration of Atlantic exotic species, which leads to a more complex vision of the recent colonization process in the entire Mediterranean and particularly in the area looked at in this paper.

\section{ACKNOWLEDGEMENTS}

The authors would like to thank Dr. J. E. Randall for suggestions for identifying I. pavo. Many thanks also to Mr. G. Triantafillou who provided a L. sceleratus specimen.

\section{REFERENCES}

Akyol, O., V. Ünal, T. Ceyhan and M. Bilecenoglu. - 2005. First confirmed record of Lagocephalus sceleratus (Gmelin, 1789) in the Mediterranean Sea. J. Fish Biol., 66: 1183-1186.

Andaloro, F. and A. Potoschi. - 1997. Ichthyofauna associated to fish aggregation devices in the southern Tyrrhenian Sea. Proceedings of a Workshop on the biology and fishery of dolphin-fish and related species, Palma de Mallorca, October 1997.

Andaloro, F. - 2001. La tropicalizzazione del Mediterraneo. In: La biodiversità nella regione biogeografica mediterranea. Versione integrata del contributo dell'ANPA al rapporto dell'EEA sulla biodiversità in Europa. pp. 52-54. Rome: A.N.P.A., Stato dell'Ambiente 4/2001.

Andaloro, F., M. Falautano, M. Sinopoli, F.M. Passarelli, C. Pipitone, P. Addis, A. Cau and L. Castriota. - 2005. The lesser amberjack Seriola fasciata (Perciformes: Carangidae) in the Mediterranean: A recent colonist? Cybium, 29(2): 141-145.

Azzurro, E. and F. Andaloro. - 2004. A new settled population of the lessepsian migrant Siganus luridus (Pisces: Siganidae) in Linosa Island- Sicily Strait. J. Mar. Biol. Ass. U. K., 84: 819-821.

Azzurro, E., F. Pizzicori and F. Andaloro. - 2004. First record of Fistularia commersonii (Fistularidae) from the Central 
Mediterranean. Cybium, 28: 72-74.

Bauchot, M.-L. - 1987. Poissons osseux. In: Fischer W., M.-L. Bauchot. and M. Schneider (eds.), Fiches FAO d'identification des espèces pour les besoins de la pêches. (Révision 1). Méditerranée et Mer Noire. Zone de pêche 37. Vol. 2: Vertébrés, pp. 891-1422. Rome: FAO.

Ben Soussi, J., J. Zaouali, M.N. Bradai and J.P. Quignard. - 2004 Lessepsian migrant fishes off the coast of Tunisia. First record of Fistularia commersonii (Osteichthyes, Fistularidae) and Parexocoetus mento (Osteichthyes, Exocoetidae). Vie Milieu, 54 (4): 247-248.

Ben Soussi, J., D. Golani, H. Mejri and C. Capapé. - 2005. On the occurrence of Cheilopogon furcatus in the Mediterranean Sea. J. Fish Biol., 67: 1144-1149.

Bradai, M.N. - 2000. Diversité du peuplement ichtyque et contribution à la connaissance des Sparidés du golfe de Sfax. Thèse d'Etat. Faculté des Sciences de Sfax.

Catalano, E. and B. Zava. - 1993. Sulla presenza di Stephanolepis diaspros Fr. Brunn. nelle Acque Italiane (Osteichthyes, Monacanthidae). Supplemento alle Ricerche di Biologia della selvaggina, 21: 379-382.

Corsini, M., P. Margies, G. Kondilatos and P.S. Economidis. 2005. Lessepsian migration of fishes to the Aegean Sea: new record of Tylerius spinosissimus (Teleostei, Tetraodontidae) from the Mediterranean, and six more fish records from Rhodes. Cybium, 29(4): 347-354.

Dulčić, J. and A. Pallaoro. - 2003. Lessepsian fish migrants reported in the Eastern Adriatic Sea: an annotated list. ANNALES. Ser. Hist. Nat., 13(2): 137-144.

Eryilmaz, L., M. Özulug and N. Meriç. - 2003. The Smooth Pufferfish, Sphoeroides pachygaster (Müller and Troschel, 1848) (Teleostei: Tetraodontidae), new to the Northern Aegean Sea. Zool. Middle East, 28: 125-126.

Froese, R. and D. Pauly (eds.). - 2005. FishBase. World Wide Web electronic publication. www.fishbase.org, version 06/2005

Golani, D., L. Orsi-Relini, E. Massutí and J.-P. Quignard. - 2002. CIESM Atlas of Exotic species in the Mediterranean. Vol. 1. Fishes (Briand F., ed.). CIESM Publishers, Monaco.

Golani, D., L. Orsi-Relini, E. Massutí and J.-P. Quignard. - 2004. Dynamics of fish invasions in the Mediterranean: update of the CIESM Fish Atlas. Rap. Comm. Int. Mer Médit., 37: 367.

Kevrekidis, K. and B.S. Galil. - 2003. Decapoda and Stomatopoda (Crustacea) of Rodos island (Greece) and the erythrean expansion NW of the Levantine sea. Medit. Mar. Sci., Vol. 4/1: 57-66.
Massutí, E. and C. Stefanescu. - 1993. First record of Seriola fasciata (Bloch, 1793) (Osteichthyes: Carangidae) in the Mediterranean. J. Fish Biol., 42: 143-144.

Oliver, P. - 1981. Sobre la aparición de algunos peces raros en las Islas Baleares. Bol. Inst. Esp. Oceanogr., VI (304): 59-64.

Pancucci-Papadopoulou, M.A., K. Kevrekidis, M. Corsini-Foka and N. Simboura. - 2005. Changes in species: invasion of exotic species. In: E. Papathanassiou and A. Zenetos (eds.), State of the Hellenic Marine Environment, pp. 336-342. HCMR Publications, Athens.

Quignard, J.P. and J.A. Tomasini. - 2000. Mediterranean fish biodiversity. Biol. Mar. Medit., 7 (3): 1-66.

Randall, J.E. - 1981. Two new species and six new records of Labrid fishes from the Red Sea. Senckenb. marit., 13: 79-109.

Randall, J.E. - 1986. Labridae. In: M.M. Smith and P.C. Heemstra (eds.), Smith's Sea Fishes, pp. 683-706. Springer-Verlag, Berlin.

Randall, J.E. and J.L. Earle. - 2002. Review of the Hawaiian Razorfishes of the Genus Iniistius (Perciformes: Labridae). Pacif. Sci., 56(4): 389-402.

Sinis, A.I. - 2005. First record of Tylosurus crocodilus (Péron and Lesueur 1821) (Pisces: Belonidae) in the Mediterranean (North Aegean Sea, Greece). $12^{\text {th }}$ Hellenic Ichthyologists Symposium Proceedings, Drama, Greece, Oct. 2005, pp. 304-307 (in Greek with English abstract).

Smith, M.M. and P.C. Heemstra. - 1986a. Tetraodontidae. In: M.M. Smith and P.C. Heemstra (eds.), Smiths' sea fishes, pp. 894903. Springer-Verlag, Berlin.

Smith, M.M. and P.C. Heemstra (eds.). - 1986b. Smiths' sea fishes. Springer-Verlag, Berlin.

Smith-Vaniz, W.F. - 1986. Carangidae. In: P.J.P. Whitehead, M.-L. Bauchot, J.-C. Hureau, J. Nielsen and E. Tortonese (eds.), Fishes of the North-eastern Atlantic and the Mediterranean, Vol. 2, pp. 815-844, UNESCO, Paris.

Streftaris, N., A. Zenetos and E. Papathanassiou. - 2005. Globalisation in marine ecosystems: the story of non-indigenous marine species across European seas. Oceanogr. Mar. Biol. Ann. Rev., 43: 419-453.

Victor, B. C., G. M. Wellington and C. Caldow. - 2001. A review of the razorfishes (Perciformes: Labridae) of the Eastern Pacific Ocean. Rev. Biol. Trop., 49 Suppl. 1: 101-110.

Scient. ed.: E. Massutí

Received April 21, 2005. Accepted December 12, 2005. 
